\title{
Role of Hydroxychloroquine within the framework of the Covid19 anaerobic hypothesis (SARS-Cov2 enables anaerobic bacteria colonization of lungs) in terms of its $\mathrm{pH}$ based mechanism of action in malaria
}

Sandeep Chakraborty

\section{Letter}

The use of hydroxychloroquine (HCQ) and azithromycin to treat Covid19 patients with success [1-3] or failure [4,5] is highly controversial - timing, protocol (usage of zinc [6] for example) and safety [7] being key considerations.

Based on evidence of colonization of the lungs by anaerobic bacteria, aided by SARS-Cov2, from sequencing data [8], a key question arises - is there basis to the fact the HCQ and azithromycin act synergistically on these bacteria?

HCQ is a lesser toxic [9] derivative of chloroquine used to prevent and treat malaria, rheumatoid arthritis [10], lupus [11], etc. HCQ is known to be involved in inhibition of cytokine production, lysosomal activity, interference with Toll-like receptor (TLR) signalling and autophagy [12]. HCQ is associated with an increased risk of retinopathy [12] and QT prolongation [7] - thus self-medication should be strictly avoided.

\section{Hemozoin biocrystallization in malaria within acidic vacuoles}

The antimalarial mechanism of action of HCQ is not fully known. The most widely accepted mechanism of action involves the aggregation of cytotoxic heme by inhibition of hemozoin biocrystallization [13]. Digestion of blood by Plasmodium releases high quantities of free heme (a pigment consisting of an iron atom), which is toxic to even the Plasmodium cells [14]. So, Plasmodium converts it into an insoluble crystalline form called hemozoin or malaria pigment [15]. These parasites degrade hemoglobin in an acidic food vacuole.

\section{HCQ is basic - and increases pH - thus inhibiting hemozoin biocrystallization}

HCQ (and chloroquine) increases pH within intracellular vacuoles and alter many processes [16]. In fact, resistance to chloroquine of malaria is due to a protein PfCRT [17], a mutation there reduces chloroquine accumulation in the digestive vacuole of the parasite [18].

\section{Heme is toxic to bacteria also - the heme pigment is formed by lowering $\mathrm{pH}$}

Heme is toxic to bacteria at high concentrations [19]. The heme pigment of Porphyromonas gingivalis differs from that generated by Prevotella, though the $\mathrm{pH}$ for both is between $5 \cdot 8$ and 6 [20]. 'The low $\mathrm{pH}$ encourages cell-surface deposition of insoluble Fe(III)PPIX.OH which would act as a barrier against oxygen and reactive oxygen species, and also protect against H2O2 through its inherent catalase activity' [20].

\section{Analogously HCQ stops heme pigment formation in anaerobic bacteria}

Disseminated intravascular coagulation (DIC) is a serious disorder characterized by small blood clots developing throughout the bloodstream, blocking small blood vessels, depleting platelets and clotting factors leading to excessive bleeding. Lately, it is been reported that Covid19 is more of a vascular problem, than one of the lungs [21-25]. In this theory, the inception of the DIC happens through hemoglobin degrading proteins [26], heme-binding proteins sequestering heme after hemoglobin degradation [27], 'plundering' iron, and thereby sequestering oxygen [28]. And a very important enzyme - hemagglutinin, which causes thrombus formation, initially in venules and then in arterioles [29]. Thus, it is hypothesized the HCQ might be having an anti-bacterial effect by stopping heme pigment formation, which would form an abscess and then a clot. 


\section{References}

1. Gautret P, Lagier JC, Parola P, Meddeb L, Mailhe M, et al. (2020) Hydroxychloroquine and azithromycin as a treatment of COVID-19: results of an open-label non-randomized clinical trial. International Journal of Antimicrobial Agents : 105949.

2. Million M, Lagier JC, Gautret P, Colson P, Fournier PE, et al. (2020) Full-length title: Early treatment of covid-19 patients with hydroxychloroquine and azithromycin: A retrospective analysis of 1061 cases in marseille, france. Travel Medicine and Infectious Disease : 101738.

3. Chen Z, Hu J, Zhang Z, Jiang S, Han S, et al. (2020) Efficacy of hydroxychloroquine in patients with covid-19: results of a randomized clinical trial. MedRxiv .

4. Magagnoli J, Narendran S, Pereira F, Cummings T, Hardin JW, et al. (2020) Outcomes of hydroxychloroquine usage in united states veterans hospitalized with covid-19. medrxiv .

5. Mahevas M, Tran VT, Roumier M, Chabrol A, Paule R, et al. (2020) No evidence of clinical efficacy of hydroxychloroquine in patients hospitalized for covid-19 infection with oxygen requirement: results of a study using routinely collected data to emulate a target trial. medrxiv .

6. Scholz M, Derwand R (2020) Does zinc supplementation enhance the clinical efficacy of chloroquine/hydroxychloroquine to win todays battle against covid-19? .

7. Chen CY, Wang FL, Lin CC (2006) Chronic hydroxychloroquine use associated with qt prolongation and refractory ventricular arrhythmia. Clinical Toxicology 44: 173-175.

8. Chakraborty S (2020). Sars-cov2 enables anaerobic bacteria (Prevotella, et al) to colonize the lungs disrupting homeostasis - symptoms (ARDS, septic shock, blood clots, arterial stroke) finds resonance, with key differences, in the 'forgotten disease' Lemierre syndrome, caused by anaerobic bacteria enabled by Epstein Barr virus. doi:10.31219/osf.io/usztn. URL osf .io/usztn.

9. Hickley NM, Al-Maskari A, McKibbin M (2011) Chloroquine and hydroxychloroquine toxicity. Archives of Ophthalmology 129: 1506-1507.

10. Smolen JS, Landewé R, Breedveld FC, Buch M, Burmester G, et al. (2014) Eular recommendations for the management of rheumatoid arthritis with synthetic and biological disease-modifying antirheumatic drugs: 2013 update. Annals of the rheumatic diseases 73: 492-509.

11. Ruiz-Irastorza G, Ramos-Casals M, Brito-Zeron P, Khamashta MA (2010) Clinical efficacy and side effects of antimalarials in systemic lupus erythematosus: a systematic review. Annals of the rheumatic diseases 69: 20-28.

12. Schrezenmeier E, Dörner T (2020) Mechanisms of action of hydroxychloroquine and chloroquine: implications for rheumatology. Nature Reviews Rheumatology : 1-12.

13. Sullivan DJ (2002) Theories on malarial pigment formation and quinoline action. International journal for parasitology 32: 1645-1653.

14. Coronado LM, Nadovich CT, Spadafora C (2014) Malarial hemozoin: from target to tool. Biochimica et Biophysica Acta (BBA)-General Subjects 1840: 2032-2041.

15. Olivier M, Van Den Ham K, Shio MT, Kassa FA, Fougeray S (2014) Malarial pigment hemozoin and the innate inflammatory response. Frontiers in immunology 5: 25.

16. Yayon A, Cabantchik ZI, Ginsburg H (1985) Susceptibility of human malaria parasites to chloroquine is ph dependent. Proceedings of the National Academy of Sciences 82: 2784-2788. 
17. Kim J, Tan YZ, Wicht KJ, Erramilli SK, Dhingra SK, et al. (2019) Structure and drug resistance of the plasmodium falciparum transporter pfcrt. Nature 576: 315-320.

18. Chinappi M, Via A, Marcatili P, Tramontano A (2010) On the mechanism of chloroquine resistance in plasmodium falciparum. PloS one 5 .

19. Anzaldi LL, Skaar EP (2010) Overcoming the heme paradox: heme toxicity and tolerance in bacterial pathogens. Infection and immunity 78: 4977-4989.

20. Smalley JW, Silver J, Birss AJ, Withnall R, Titler PJ (2003) The haem pigment of the oral anaerobes prevotella nigrescens and prevotella intermedia is composed of iron (iii) protoporphyrin ix in the monomeric form. Microbiology 149: 1711-1718.

21. Tang N, Li D, Wang X, Sun Z (2020) Abnormal coagulation parameters are associated with poor prognosis in patients with novel coronavirus pneumonia. Journal of Thrombosis and Haemostasis .

22. Cui S, Chen S, Li X, Liu S, Wang F (2020) Prevalence of venous thromboembolism in patients with severe novel coronavirus pneumonia. Journal of Thrombosis and Haemostasis .

23. Kollias A, Kyriakoulis KG, Dimakakos E, Poulakou G, Stergiou GS, et al. (2020) Thromboembolic risk and anticoagulant therapy in covid-19 patients: Emerging evidence and call for action. British Journal of Haematology .

24. Leisman DE, Deutschman CS, Legrand M Facing covid-19 in the icu: vascular dysfunction, thrombosis, and dysregulated inflammation. Intensive Care Medicine : 1.

25. Choi MH, Jung JI, Chung WD, Kim YJ, Lee SE, et al. (2014) Acute pulmonary complications in patients with hematologic malignancies. Radiographics 34: 1755-1768.

26. Guan SM, Nagata H, Shizukuishi S, Wu JZ (2006) Degradation of human hemoglobin by Prevotella intermedia. Anaerobe 12: 279-282.

27. Tong Y, Guo M (2009) Bacterial heme-transport proteins and their heme-coordination modes. Archives of biochemistry and biophysics 481: 1-15.

28. Ndongo S, Khelaifia S, Lagier JC, Raoult D (2019) From anaerobes to aerointolerant prokaryotes. Human Microbiome Journal : 100068.

29. Okamoto M, Maeda N, Kondo K, Leung KP (1999) Hemolytic and hemagglutinating activities of prevotella intermedia and prevotella nigrescens. FEMS microbiology letters 178: 299-304. 